\title{
SCRIPTURAL REASONING: PERAN KITAB KEAGAMAAN DALAM PENDIDIKAN AGAMA MULTIKULTURAL DI YOUNG INTERFAITH PEACEMAKER COMMUNITY INDONESIA
}

\author{
Gabriel James Angkouw \\ Fakultas Teologi Universitas Kristen Satya Wacana, Salatiga \\ angkouwjames@gmail.com \\ Iky Sumarthina Putri Prayitno \\ Fakultas Teologi Universitas Kristen Satya Wacana, Salatiga \\ iky.prayitno@uksw.edu
}

\begin{abstract}
This article is aimed at seeing the existence of religious scriptures that are able to be the basis of multicultural religious education for youth. The role of religious scriptures in the interfaith dialogue especially for Christian and Muslim youth is embodied in Scriptural Reasoning (SR), a regular activity of Young Interfaith Peacemaker Community (YIPC) Indonesia. SR is able to be a medium for interfaith interaction by making religious scriptures (Holy Bible and Koran) foundation that is also supported by YIPC principles, 12 Peace Values, and A Common Word (ACW) document. The results of this study show that religious scriptures are able to legitimate the dialogue and able to build collective identity among Christian and Muslim youth. This article is a part of qualitative research that shows the data with descriptive analytical method, especially on multicultural religious education developed by Hope S. Antone in order to show the role of religious scriptures in building solidarity of interfaith youth as the shaper of collective identity as well as the source of dialogue legitimacy. This scripturesbased multicultural religious education in the form of $S R$ is expected to be an offer in the application of religious education in Indonesia to foster mutual acceptance and tolerance.
\end{abstract}

Keywords: Religious Scriptures, Scriptural Reasoning, Multicultural Religious Education

Abstrak
Artikel ini bertujuan untuk melihat keberadaan Kitab keagamaan yang mampu
menjadi landasan pendidikan agama multikultural bagi generasi muda. Peran kitab
keagamaan dalam dialog lintas iman khususnya bagi generasi muda Kristen dan
Islam, terwujud melalui Scriptural Reasoning (SR), yang menjadi kegiatan rutin 
Young Interfaith Peacemaker Community (YIPC) Indonesia. SR mampu menjadi ruang interaksi lintas iman dengan menjadikan kitab keagamaan (Alkitab dan AlQur'an) sebagai landasan yang juga didukung dengan nilai-nilai dasar YIPC, 12 Nilai Perdamaian, serta dokumen A Common Word (ACW). Hasil dari kajian ini menunjukkan bahwa, pertama, Kitab keagamaan mampu melegitimasi dialog. Kedua, Kitab keagamaan mampu membangun identitas bersama di antara generasi muda Kristen dan Islam. Artikel ini menjadi bagian dalam kajian menggunakan metode kualitatif dengan menyajikan data secara deskriptif-analitis terkhususnya berkaitan dengan pendidikan agama multikultural yang dikembangkan oleh Hope S. Antone guna menunjukkan peran kitab keagamaan dalam membangun solidaritas generasi muda lintas agama sebagai pembentuk identitas bersama serta sumber legitimasi dialog. Metode pendidikan agama multikultrual berbasis kitab keagamaan dalam bentuk SR ini, diharapkan mampu menjadi tawaran dalam penerapan pendidikan agama di Indonesia guna menumbuhkan rasa saling menerima dan menghargai perbedaan.

\section{Kata kunci: Kitab Keagamaan, Scriptural Reasoning, Pendidikan Agama Multikultural}

\section{Pendahuluan}

Tidak bisa dimungkiri bahwa relasi antar umat Islam dan Kristen di Indonesia sering mengalami gesekan yang tak jarang berujung konflik. Sikap eksklusif dan saling membenarkan ajaran masing-masing keyakinan, menjadi salah satu pendorong semakin merenggangnya hubungan dan relasi antar kedua agama tersebut. ${ }^{1}$ Pemahaman yang dilandaskan pada kitab keagamaan masing-masing keyakinan sering menjadi dasar terciptanya sikap eksklusif yang membenarkan diri dan menyalahkan keyakinan lain. Begitu banyak pengajaran yang memuat asumsi dan prasangka terhadap keyakinan lain. ${ }^{2}$ Lembaga pendidikan tidak luput dari hal tersebut. Pendidikan yang hadir di tingkat dasar hingga perguruan tinggi tidak jarang mengajarkan doktrin-doktrin keagamaan yang membawa naradidik pada sikap fanatisme agama. ${ }^{3}$ Seperti halnya yang terjadi pada awal tahun 2020 , dimana seorang pembina Pramuka mengajarkan yel-yel bernuansa intoleransi

1 Cherian George, Pelintiran Kebencian: Rekayasa Ketersinggungan Agama dan Ancamannya bagi Demokrasi (Jakarta: PUSAD Paramadina, 2017), 272.

2 Murdianto, "Stereotipe, Prasangka dan Resistensinya: Studi Kasus pada Etnis Madura dan Tionghoa di Indonesia". Qalamuna: Jurnal Pendidikan, Sosial, dan Agama 10, (November, 2011), 139.

${ }^{3}$ Mohamad Yusuf et al., Politik Pendidikan Agama Kurikulum 2013 dan Ruang Publik Sekolah (Yogyakarta: CRCS UGM, 2014), $39 \& 45$. 
dalam kegiatan Pramuka salah satu Sekolah Dasar di Yogyakarta. Riset MAARIF Institute terhadap Sekolah Menengah Atas di 6 kota di Indonesia pun menunjukkan adanya bibit-bibit paham radikalisme dan eksklusifisme di kalangan siswa sehingga beberapa siswa menolak untuk hormat saat upacara bendera. ${ }^{4}$ Selain itu, riset terhadap 10 Perguruan Tinggi Negeri yang dilakukan oleh SETARA Institute pada tahun 2019, menyebutkan adanya penguatan eksklusifisme keagamaan di kalangan mahasiswa. ${ }^{5}$ Tentu hal ini menjadi tantangan yang besar bagi dunia pendidikan di tengah masyarakat Indonesia yang sangat beragam termasuk dalam keberagaman keyakinan. Telah banyak dialog antar agama yang dilakukan namun hanya terjalin pada aras pemimpin-pemimpin agama saja, sementara umat sangat jarang dilibatkan. Tidak hanya itu, dialog yang dilakukan juga cenderung menampilkan ketidakjujuran dalam melihat realitas kehidupan keberagamaan di Indonesia. Apa yang ditampilkan dalam setiap dialog justru hanya mencari persamaan dalam setiap agama sebagai titik temu dan kurang menonjolkan fakta perbedaan yang ada di antara agama. ${ }^{6}$

Young Interfaith Peace Community (YIPC) Indonesia menjadi salah satu komunitas yang menghadirkan ruang-ruang dialog diantara umat Islam dan Kristen di Indonesia. Komunitas yang bergerak dalam bidang dialog lintas iman ini menyasar generasi muda guna mewujudkan generasi damai. Ruang yang melampaui dialog terwujud dalam kegiatan Scriptural Reasoning (SR) yang mendasari diskusi dengan kitab keagamaan dalam hal ini Al-Qur'an maupun Alkitab. Diskusi yang dibangun bukan bertujuan untuk mencari persamaan melainkan menggali serta menghadirkan pemahaman dan pandangan yang berbeda-beda atas dasar kitab keagamaan. SR dapat menjadi model baru dalam proses pendidikan di lembaga pendidikan yang ada sehingga kitab keagamaan bukan menjadi dasar sikap fanatik melainkan menjadi dasar kesadaran akan penghargaan keberagaman khususnya dalam lingkup Islam dan Kristen. Dalam

\footnotetext{
${ }^{4}$ Pelajar SMA di Padang, Sukabumi, dan Solo dianggap Paling Rentan Terpapar Radikalisme. BBC Indonesia. https://www.bbc.com/indonesia/amp/indonesia-42832938 (diakses 17 Mei 2020).

${ }^{5}$ SETARA Institute, Tipologi Keragaman Mahasiswa: Survei di 10 Perguruan Tinggi Negeri (Jakarta: SETARA Institute, 2019), 4-6.

${ }^{6}$ George, Pelintiran Kebencian, 173.
} 
hal ini SR menjadi proses pendidikan multikultural yang melewati batas agama namun tetap berlandaskan pada kitab-kitab keagamaan baik Al-Qur'an maupun Alkitab guna menumbuhkan sikap inklusif serta penghargaan akan perbedaan.

Dalam artikel ini penulis hendak memaparkan bagaimana kitab keagamaan masing-masing keyakinan mampu menjadi dasar dalam proses dialog lintas iman yang dapat menjadi ruang dialog serta media belajar bersama dengan justru menonjolkan perbedaan pemahaman dan pandangan dibanding mencari persamaan di antara perbedaan yang ada. Peran kitab keagamaan dalam SR yang merupakan kegiatan rutin YIPC akan menjadi fokus kajian penulis dimana mahasiswa Kristiani dan Muslim yang mengikutinya membaca dan merenungkan serta mengambil nilai-nilai kemanusiaan melalui cerita dalam kitab keagamaannya masing-masing. Keterhubungan dan kemungkinan kegiatan SR menjadi metode baru dalam pendidikan agama di lembaga pendidikan juga akan menjadi topik bahasan dalam artikel ini. Dalam konteks keberagaman di Indonesia dibutuhkan metode baru dalam dialog yang menyertakan identitas keagamaannya. Kitab Keagamaan yang digunakan dalam proses SR menjadi salah satu pelibatan identitas keagamaan dalam dialog antar generasi muda Kristen dan Islam. Maka dari itu artikel ini akan tetap memerhatikan pilar pendidikan serta teori pendidikan agama multikultural berdasarkan pemahaman Hope S. Antone dalam menggali peran SR bagi pemahaman lintas iman guna menjadikan insan-insan agama yang inklusif, dan saling menghargai satu dengan yang lain, di tengah konteks keberagaman.

Kajian terhadap pendidikan agama multikultural telah dibahas oleh Baidhawy, yang menawarkan pendidikan agama berwawasan multikultural dengan pendekatan dialogis guna menanamkan kesadaran hidup bersama dalam perbedaan dan keberagaman. ${ }^{7}$ Demikian juga dengan Ibrahim, yang melihat pendidikan multikultural mampu menjadi langkah pencegahan konflik di tengah

7 Zakiyuddin Baidhawy, Pendidikan Agama Berwawasan Multikultural (Jakarta: Erlangga, 2005), 2. 
realitas keragaman di Indonesia. ${ }^{8}$ Susanto pun memandang bentuk pendidikan agama multikutural bertujuan untuk menampilkan sisi agama yang lebih santun, dialogis, serta apresiatif terhadap keragaman yang ada serta mampu mengatasi permasalahan hidup bersama. ${ }^{9}$ Jackson, di lain sisi memandang pendidikan agama sudah seharusnya mempertimbangkan kemajemukan dalam konteks masyarakat untuk menghadirkan pengalaman terhadap pluralitas. ${ }^{10}$ Sementara itu, Ling dan Fui melihat olah raga sepak bola mampu menjadi media pertemuan serta ruang untuk megalami kemajemukan yang ada antara sekolah dengan latar belakang Muslim-Malaysia (Madrasah) dan sekolah swasta etnis Tionghoa di Singapura. ${ }^{11}$ Mempertimbangkan multikulturalisme dalam jalannya pendidikan juga turut menjadi perhatian Race, yang mendorong diajarkannya nilai-nilai toleransi, penerimaan diri dan sesama, serta berlangsungnya dialog. ${ }^{12}$ Namun, kajian dalam artikel ini berbeda dengan apa yang telah menjadi kajian dari para tokoh di atas karena dalam artikel ini pendidikan agama multikulturalisme didasari dengan kitab keagamaan masing-masing komunitas agama yang dalam landasan masingmasing identitas keagamaan mampu membentuk identitas bersama.

Artikel ini akan dibagi dalam empat bagian. Pertama, penulis akan memaparkan signifikansi pendidikan agama berbasis Kitab Keagamaan di Indonesia dalam konteks masyarakat multikultural serta menyajikan kajian teori pendidikan Agama Multikultural terhadap SR sebagai model baru pendidikan inklusif bagi pendidikan generasi muda di Indonesia. Kedua, penulis akan memaparkan proses SR dan landasannya serta melihat peran kitab keagamaan sebagai dasar dari 12 nilai perdamaian yang ditanamkan sebelum proses SR dan hubungannya dengan dokumen A Common Word dalam dialog lintas iman Kristen-Islam. Ketiga, penulis akan mengkaji kemungkinan SR sebagai media

\footnotetext{
${ }^{8}$ Ruslan Ibrahim, "Pendidikan Multikultural: Upaya Meminimalisir Konflik dalam Era Pluralitas Agama”, el-Tarbawi: Jurnal Pendidikan Islam, vol.1 no. 1 (2008), 116.

${ }^{9}$ Edi Susanto, "Pendidikan Agama berbasis Multikultural (Upaya Strategis Menghindari Radikalisme)", KARSA, vol.ix no.1 (April, 2006), 783.

10 Robert Jackson, Rethinking Religious Education and Plurality (New York: RoutledgeFalmer, 2004), 4-5.

${ }^{11}$ Ooi Giok Ling dan Chee Min Fui, "They Play Soccer too!-Madrasah Education in Multicultural Singapore", Asia Pasific Journal of Education 27: 1 (Maret, 2007), 79.

${ }^{12}$ Richard Race, Multiculturalism and Education (London: Continuum, 2011), 6.
} 
pendidikan agama multikultural Kristen-Islam bagi generasi muda yang juga mampu mencakup masyarakat secara luas. Keempat, akan berisi kesimpulan.

\section{Young Interfaith Peacemaker Community sebagai Penggagas Scriptural Reasoning di Indonesia}

Scriptural Reasoning (SR) merupakan salah satu kegiatan yang dilaksanakan oleh komunitas Young Interfaith Peacemaker Community (YIPC) Indonesia yang melibatkan kaum muda Kristiani dan Muslim dari berbagai daerah di Indonesia. Komunitas YIPC Indonesia merupakan salah satu komunitas yang bergerak dalam bidang dialog lintas agama khususnya dalam dialog Islam-Kristen. Terbentuknya YIPC Indonesia tidak terlepas dari dilaksanakannya kegiatan Young Peacemaker Training oleh dua orang mahasiswa Indonesian Consortium for Religious Studies (ICRS) UGM Yogyakarta, yakni Andreas Jonathan dan Ayi Yunus Rusyana. Kegiatan yang dilaksanakan pada Juli 2012 ini diikuti oleh 25 orang mahasiswa strata satu dengan latar belakang agama Kristen dan Islam. Sebagai bentuk tindak lanjut dari kegiatan ini dilaksanakanlah beberapa kegiatan seperti dialog lintas iman dan kajian kitab keagamaan. Pada akhirnya kegiatan ICRS menggagas kegiatan Student Interfaith Peace Camp (SIPC) 2012 yang diikuti oleh 30 orang peserta. Pada perkembangan selanjutnya SIPC dilaksanakan di tiga kota besar yakni Jogja, Medan, dan Surabaya yang ditindaklanjuti dengan dialog rutin setiap minggunya dimana SR turut dilaksanakan. Pada masa ini nama yang digunakan ialah Young Peacemaker Community (YPC) Indonesia.

Pada tahun 2013, bertempat di Magelang, dilaksanakanlah Konfrensi Nasional yang diikuti oleh 50 peserta dari berbagai kota di Indonesia dengan mengangkat tema "Loving God-Loving Others, Let's Do Something About It". Pada akhir konferensi ini disempurnakanlah nama Young Peacemaker Community (YPC) menjadi Young Interfaith Peacemaker Community (YIPC) Indonesia. Hingga tahun 2019, YIPC Indonesia telah melaksanakan SIPC di berbagai regional seperti di Surabaya, Bandung, Malang, Jogja, Jakarta, Jawa Tengah (pengembangan dari regional Salatiga), dan Medan. Di samping SIPC, YIPC Indonesia juga melaksanakan kegiatan rutin seperti Training for Fasilitator, serta 
Interfaith Peacemaker National Conference. Pada dasarnya kegiatan SIPC yang dialaksanakan oleh YIPC Indonesia hanya dikhususkan bagi kaum muda Kristiani dan Muslim, namun dalam kegiatan lainnya YIPC tetap melibatkan kaum muda dengan latar belakang agama di luar Kristen dan Islam. ${ }^{13}$

Kegiatan SIPC menjadi awal diperkenalkannya kegiatan SR kepada peserta yang kemudian akan menjadi bagian dari anggota YIPC Indonesia. Dalam konteks Indonesia, SR masih menjadi hal yang baru dalam dialog Islam-Kristen, dan YIPC melalui kegiatan SIPC menjadi penggagasnya dalam mewadahi dialog kaum muda Kristiani dan Muslim. SR merupakan suatu kegaiatan yang bermula di Amerika Utara pada awal tahun 1990an. Pada awalnya SR berbentuk Textual Reasoning (TR) yakni suatu forum studi berbasis universitas yang dilakukan oleh para cendekiawan Yahudi (yang tergabung dalam cendekiawan Filsafat Modern Yahudi dan cendikiawan Teks Rabbinik) dengan tujuan untuk menumbuhkan pemahaman terhadap disiplin ilmu yang berbeda serta untuk menjawab pertanyaan kunci mengenai Yudaisme pada masa itu dan pada masa selanjutnya. ${ }^{14}$ Pada pertengahan tahun 1990, beberapa kerabat Kristen duduk bersama dalam forum tersebut dan merasa sangat tertarik dengan proses yang terjadi dalam forum tersebut. Forum tersebut dianggap dapat digunakan sebagai model baru dalam dialog antar agama. Dalam forum berikutnya, mereka mengundang rekan Muslim untuk turut serta dalam forum tersebut, dan pada saat itulah Scriptural Reasoning bermula. Peserta Kristiani pertama berasal dari Inggris dan praktik SR kemudian menyebar sampai ke Atlantik dan juga turut berkembang dalam komunitaskomunitas non-akademik. Hingga kini SR menjadi kegiatan rutin yang dilaksanakan oleh program kerja Lintas Iman Universitas Cambridge. ${ }^{15}$

13 YIPC Indonesia. Laporan Tahunan YIPC Indonesia 2018. http://yipci.org/laporantahunan-yipc-indonesia-2018 (diakses 22 Januari 2020).

${ }^{14}$ David E. Ford, “An Interfaith Wisdom: Scriptural Reasoning Between Jews, Christians, and Muslims", Modern Theology 22 (Juni, 2006), 346.

${ }^{15}$ David E. Ford. Jews, Christians, and Muslims Meet around their Scriptures: An Interfaith Practice for the $21^{\text {st }}$ Century (Rome: The Russell Berrie Foundation, 2011) xiii. 


\section{Landasan dan Proses Scriptural Reasoning}

Mengawali kegiatan SIPC, fasilitator YIPC menyajikan berbagai topik materi mengenai hubungan lintas iman Kristen dan Islam, di antaranya ialah mengenai nilai-nilai landasan YIPC, 12 Nilai perdamaian, serta dokumen A Common Word. Materi yang diberikan menjadi awal pembekalan sebelum masuk dalam kegiatan SR. Nilai-nilai landasan YIPC ialah, 1) Berdamai dengan Allah dengan megakui Allah Yang Maha Esa sebagai pencipta dan satu-satunya yang disembah serta mengasihi Allah dengan segenap hati, segenap akal budi, dan segenap kekuatan. 2) Berdamai dengan Diri Sendiri yakni menerima diri sebagai ciptaan Tuhan yang unik dengan penuh syukur. 3) Berdamai dengan Sesama yakni mengasihi sesama seperti diri sendiri, menerima dan menghormati keberadaan dan keberagaman, serta menolak segala bentuk kekerasan dalam menyelesaikan konflik secara langsung (meminta maaf dan memaafkan). 4) Berdamai dengan Lingkungan. ${ }^{16}$ Nilai selanjutnya yang ditanamkan ialah 12 Nilai Perdamaian mencakup, 1) Menerima Diri Sendiri, 2) Prasangka dan Curiga, 3) Keanekaragaman Suku, 4) Keberagaman Agama, 5) Perbedaan Status Gender, 6) Status Ekonomi, 7) Berkelompok, 8) Perbedaan, 9) Menyelesaikan Konflik, 10) Kekerasan, 11) Mengaku Salah, 12) Mengampuni dan Memaafkan. ${ }^{17}$ Peserta juga diperkenalkan dengan dokumen A Common Word (ACW) yang merupakan suatu surat dari 38 otoritas dan cendekiawan Islam di seluruh dunia sebagai tanggapan atas pidato Paus Benediktus XVI pada 13 September 2006 di Regensburg. Surat ini berisikan pandangan cendekiawan Islam terhadap landasan yang sama antara Islam dan Kristen. ${ }^{18}$

Dengan landasan nilai-nilai serta materi tersebut, peserta SIPC lalu diperkenalkan dengan SR. Proses SR sendiri melibatkan tiga kitab keagamaan, yakni Kitab Taurat, Injil, dan Al-Qur'an. Adapun langkah-langkah dalam

\footnotetext{
16 YIPC Indonesia. Laporan Tahunan YIPC Indonesia 2018. http://yipci.org/laporantahunan-yipc-indonesia-2018 (diakses 22 Januari 2020).

${ }^{17}$ Erick Lincoln dan Irfan Amalee, Peace Generation: 12 Nilai Dasar Perdamaian (Bandung:Pelangi Mizan, 2007) 8.

${ }^{18}$ Sebuah Persamaan diantara Kami dan Kamu (Jordan: The Royal Aal al-Bayt Institute for Islamic Thought, 2007), 3.
} 
melakukan SR ialah sebagai berikut: Pertama, peserta mengidentifikasi suatu narasi atau tema atau juga suatu perhatian khusus maupun isu yang berkembang di tengah komunitas sesuai konteks masing-masing. Kedua, masing-masing komunitas iman memilih suatu bagian dari dalam kitab keagamaan mereka yang berhubungan dengan tema yang dipilih. Ketiga, peserta dipertemukan dalam suatu kelompok kecil dimana mereka akan membacakan setiap bagian kitab keagamaan dengan keras. Dalam bagian ini sering juga didahului dengan penjelasan mengenai bagian dari kitab keagamaan yang dibacakan guna memperkenalkan kitab keagamaan tersebut pada mereka yang mungkin saja belum pernah secara langsung berhubungan dengan kitab keagamaan komuitas iman yang lain. Keempat, dengan arahan fasilitator, para peserta kemudian mendiskusikan tema yang telah dipilih berkaitan dengan bagian kitab keagamaan yang dibaca dan didengar. Dalam diskusi ini fasilitator dapat memberikan pertanyaan maupun mendorong peserta untuk menyampaikan perenungan mereka terhadap bagian kitab keagamaan yang dibaca. Dalam proses diskusi ini, pendalaman terhadap nilai-nilai yang terkandung di dalam kitab keagamaan yang beragam dapat direnungkan bersama secara mendalam dan juga dapat saling mengklarifikasi tentang prasangka-prasangka yang ada terhadap komunitas iman yang berbeda. ${ }^{19}$ Diskusi SR tidak bertujuan untuk menghasilkan suatu kesepakatan melainkan justru menonjolkan perbedaan yang dapat berupa pertanyaan, ketidaksetujuan dengan pendapat maupun teks kitab keagamaan komunitas iman lain, serta interpretasi yang berbeda dari masing-masing peserta terhadap teks kitab keagamaan dari komuitas iman yang lain dari apa yang diyakininya.

\section{Scriptural Reasoning dan Peran Kitab Keagamaan}

Dialog antar agama khususnya Islam dan Kristen menjadi cara yang efektif untuk mempertemukan kedua komunitas iman agar dapat saling bertukar pikiran, membangun relasi, serta secara bersama-sama menjawab persoalan kehidupan

\footnotetext{
${ }^{19}$ David E. Ford, “An Interfaith Wisdom: Scriptural Reasoning Between Jews, Christians, and Muslims”, Modern Theology 22 (Juni, 2006), 346.
} 
bersama dalam bingkai keutuhan ciptaan. ${ }^{20} \mathrm{SR}$ menjadi bagian dari dialog serta dalam mewujudkan tujuan tersebut. Dalam kajian dialog lintas agama, studi intertekstual dikembangkan menjadi studi kultural dimana dialog dibangun dalam relasi kebudayaan (tarian, pepatah, puisi, ritus, dan lainnya) untuk dapat saling membangun pemahaman bersama serta aksi bersama. ${ }^{21}$ Bagi penulis, dialog berlandaskan kearifan lokal perlu diimbangi dengan dialog intertekstual. Dalam konteks Asia, dialog antar agama setidaktnya dilandaskan pada tiga hal yakni: pertama, berladaskan ekspresi kebudayaan. Kedua, berlandaskan identitas keagamaan seperti kitab keagamaan, ritual, serta tradisi lisan yang ada. Ketiga, berlandaskan pada gerakan sosial dalam menghadapi permasalahan sosial seperti halnya, permasalahan ekologi, dan kemiskinan. ${ }^{22}$ Dapat dilihat bahwa dialog intertekstual seperti halnya SR, masih diperlukan dalam membangun dialog lintas agama. Dilibatkannya kitab keagamaan dalam proses dialog mampu melegitimasi serta menghadirkan ruang pertemuan antar identitas, dalam hal ini identitas Kristen dan Islam. Menjadi hal yang menarik bahwa dalam konteks Indonesia, SR justru dilaksanakan dalam komuitas generasi muda, berbeda dengan yang dilaksanakan dalam komunitas dimana ia dilahirkan yang hanya mencakup para pemimpin komunitas. Hal ini tentu menjadi kelebihan penyelenggaraan SR di YIPC Indonesia. Telah dibahas sebelumnya bagaimana SR dilandasai dengan nilai dasar YIPC, 12 Nilai Perdamaian, maupun dokumen ACW yang semuanya dilandaskan atas kitab keagamaan dalam komunitas Islam dan Kristen. Pada bagian ini penulis akan memaparkan peranan kitab keagamaan yang terbagi dalam dua bagian bahasan yakni, pertama, peran kitab keagamaan dalam membentuk identitas bersama dan kedua, peran kitab keagamaan dalam melegitimasi dialog Kristen-Islam.

${ }^{20}$ Yusak B. Setyawan, "Encountering State Ideology: Reading the Bible from an Indonesian Postcolonial Perspective" dalam Colonial Contexts and Postcolonial Theologies: Storyweaving in The Asia-Pasific, ed. Mark G. Brett dan Jione Havea (New York: Palgrave Macmillan, 2014), 104.

21 Izak Y.M. Lattu, "Beyond Interreligious Dialogue: Oral-Based Interreligious Engagements in Indonesia" dalam Interreligious Dilaogue: From Religion to Geopolitic, ed. Giuseppe Giordan, dan Andrew P. Lynch (Boston: Brill, 2019), 71.

${ }^{22}$ Lattu, Beyond Interreligious Dialogue, 72. 


\section{Kitab Keagamaan Membentuk Identitas Bersama}

Kitab keagamaan tidak dapat dilepaskan dari kehadiran agama. Bagi Yusak Setyawan masing-masing agama memiliki kekhasannya tersendiri dengan klaim kebenarannya yang bersumber dari kitab keagamaan yang juga turut mengatur setiap segi kehidupan keagamaan. ${ }^{23}$ Dapat dikatakan bahwa kitab keagamaan menjadi dasar kehidupan keagamaan yang juga mengandung doktrin dan menjadi identitas masing-masing agama. Sebagai identitas komunitas agama, kitab keagamaan mengandung pengakuan akan Yang Transenden (credo), pengakuan ini mewujud dalam bentuk-bentuk ekspresi penyembahan (cult) yang juga mengikat pemeluk-pemeluknya pada aturan-aturan tertentu (code). ${ }^{24}$ Dalam hal ini, Al-Qur'an menjadi perwujudan identitas bagi umat Islam, dan Alkitab menjadi perwujudan identitas bagi umat Kristen dimana kehidupan masingmasing agama bersumber dari kitab keagamaan yang khas tersebut. Dengan demikian, kehadiran SR dalam hal ini menjadi ruang pertemuan identitas IslamKristen dimana kitab keagamaan masing-masing agama mampu dijadikan dasar bersama baik melalui 12 Nilai Perdamaian, serta ACW yang turut menghasilkan pemahaman bersama untuk mencapai situasi damai sebagai dasar pengajaran masing-masing agama.

Pada bagian ini penulis hendak memaparkan bahwa dengan mempertemukan dua identitas yang berbeda atas dasar landasan kitab keagamaan masing-masing komunitas iman, mampu menciptakan suatu identitas baru di antara kedua komuintas iman. Identitas tersebut membentuk identitas bersama dengan dasar identitas keagamaan masing-masing komunitas yang didalamnya terkandung nilai, makna, serta keyakinan dalam wujud kebudayaan masingmasing komunitas iman. Nilai-nilai tersebut menjadi dasar persamaan persepsi tentang nilai-nilai keagamaan yang dalam perbedaan justru memiliki tujuan yang sama yakni mengasihi Allah dan sesama. Identitas bersama yang menyatukan

${ }^{23}$ Yusak B. Setyawan, "Konflik dan Kekerasan Bernuansa Keagamaan di Indonesia dalam Perspektif Pandangan Yesus, dalam Injil-injil Kanonis Perjanjian Baru” dalam Perdamaian dan Keadilan (Jakarta: BPK Gunung Mulia, 2017), 18.

${ }^{24}$ Setyawan, Konflik dan Kekerasan, 6. 
komunitas iman Kristen dan Islam memiliki dasar yang kuat karena dibangun atas dasar nilai dalam masing-masing keyakinan. Nilai yang diangkat secara langsung dari kitab keagamaan masing-masing komunitas iman mampu melegitimasi dialog antar kedua agama tersebut karena pertama-tama telah dipersatukan dalam suatu pemahaman bersama. Consensus-buliding antar dua komunitas yang menghasilkan identitas bersama terbentuk. ${ }^{25}$ Dengan kata lain di antara perbedaan komunitas Kristen dan Islam terbentuk suatu ikatan sukarela dan ikatan ini dilandasi oleh kitab keagamaan dimana identitas perdamaian hadir dan menyatukan kedua komunitas keagamaan.

Kitab keagamaaan sebagai bagian yang tidak terpisahkan dari suatu komunitas keagamaan menjadi bagian dari identitas serta landasan kehidupan keagamaan dalam masing-masing komunitas. Pengalaman sangat memiliki peran penting dalam komunitas keagamaan terlebih ketika pengalaman tersebut diwujudkan dalam simbol-simbol religius dimana individu mempertautkan dirinya dan keberadaannya sebagai manusia dalam kebudayaan yang terkandung di dalam komunitas iman. ${ }^{26}$ Kitab keagamaan tidak terlepas dari kebudayaan dan komunitas karena pada dasarnya kitab keagamaan dihasilkan dari kebudayaan yang mencakup nilai, makna, keyakinan yang mampu mengkoordinasi serta mengontrol interaksi manusia serta mampu membangun suatu jejaring untuk mentransmisikan sistem yang dibangun dari satu generasi ke generasi selanjutnya. Kitab keagamaan menjadi bagian dalam kehidupan sosial yang turut dalam interaksi dengan teks-teks sosial. ${ }^{27}$ Maka dari itu teks keagamaan sangat sarat dengan ideologi yang berperan dalam mengarahakan setiap manusia dalam komunitas agama dalam berperilaku baik dalam tindakan maupun ucapan. Melandasi dialog lintas iman dengan kitab keagamaan yang menjadi identitas

\footnotetext{
25 Izak Y.M. Lattu, Menolak Narasi Tunggal: Diskursus Agama, Pluralisme, dan Demokras (Salatiga: Satya Wacana University Press, 2018), 144-145.

${ }^{26}$ Robert N. Bellah, Beyond Belief: Essays on Religion in a Post-Traditional World (Berkley: University of California Press, 1970), 195.

27 Yusak B. Setyawan, "Kitab Keagamaan, Ideologi, Budaya dan Komunitas" (dipresentasikan dalam kelas Mata Kuliah Kitab-Kitab Keagamaan dan Maysarakat untuk Magister Sosiologi Agama Fakultas Teologi UKSW, Salatiga, 16 Oktober 2019).
} 
masing-masing komunitas iman mampu mendorong sikap keterbukaan di antara komunitas iman untuk dapat saling menerima perbedaan.

Berkaitan dengan hubungan antar agama yang dibangun dalam SR dengan landasan kitab keagamaan, dapat terlihat adanya pertemuan ideologi, pertemuan antar kebudayaan yang berbeda namun saling berinterkasi. Kitab keagamaan sangat beresiko untuk menghasilkan perselisihan akibat dari ideologi yang dikandungnya berbeda antar satu komunitas iman dengan yang lainnya. Terlebih dalam komunitas agama yang terbentuk, masing-masing agama sangat terikat dengan aspek afeksi pemeluknya. Dengan kata lain, fungsi emosional yang terkandung dalam agama sangat berpengaruh dalam pengalaman bersesama antar komunitas iman karena telah menyangkut perasaan kolektif yang menjadi identitas diri dari setiap komunitas iman. ${ }^{28}$ Dalam konteks Indonesia, perebedaan ideologi terhadap pemahaman akan kitab keagamaan sering menghasilkan konfilk yang pada dasarnya didasari atas ketidakmengertian serta asumsi dan prasangka yang dibangun dalam masing-masing komunitas iman sehingga pada akhirnya membentuk masyarakat yang eksklusif. ${ }^{29}$ Mendasari dialog lintas agama dengan kitab keagamaan menjadi hal yang perlu dikembangkan.

\section{Kitab Keagamaan Melegitimasi Dialog Kristen-Islam}

Bagi David Ford jantung agama terletak pada kitab keagamaan. ${ }^{30}$ Melalui kitab keagamaan setiap pemeluk agama dalam komunitas agama dihubungkan dengan konsep kehadiran yang Ilahi yang juga turut membentuk hubungan personal sehingga setiap pemeluk agama menjalankan kehidupan sosialnya mengacu dan berpedoman pada kitab keagamaan. Dengan kata lain, kitab keagamaan mengandung pemahaman fundamental terhadap Yang Ilahi serta eksistensi kehidupan setiap pemeluk agama. ${ }^{31}$ Kitab keagamaan pada dasarnya merupakan

\footnotetext{
${ }^{28}$ John A. Saliba, Understanding New Religious Movements (Oxford: AltaMira, 2003), 147.

29 Cherian George, Pelintiran Kebencian: Rekayasa Ketersinggungan Agama dan Ancamannya bagi Demokrasi (Jakarta: PUSAD Paramadina, 2017), 21.

${ }^{30}$ David E. Ford. Fields of Faith: Theology and Religious Studies for the Twenty-First Century (New York: Cambridge University Press, 2005) 34.

${ }^{31}$ Peter Ochs "Scripture", dalam Fields of Faith: Theology and Religious Studies for the Twenty-First Century. (New York: Cambridge University Press, 2005), 104.
} 
suatu pedoman hidup bagi pemeluknya yang di dalamnya mengandung tuntunan moral, etika, ideologi, tradisi, serta kisah-kisah sejarah sebagai bagian dari tuntunan hidup yang bermakna bagi manusia dalam membangun keyakinan serta hubungannya dengan Yang Ilahi maupun dalam mengatur relasi kehidupan. ${ }^{32}$ Dalam Islam sendiri, Al-Qur'an menjadi bagian dari Rukun Iman yang pada dasarnya bersumber pada keberadaan Al-Qur'an itu sendiri sebagai Firman Allah melalui Nabi Muhammad saw., yang di dalamnya terkandung petunjuk kehidupan bagi umat Muslim serta inti iman mengenai konsep Tauhid sebagai jantung iman Islam. ${ }^{33}$ Dalam konteks Kristen, Alkitab juga menjadi dasar iman umat yang juga mengatur kehidupan umat sebagai bentuk aktualisasi iman terhadap Yang Ilahi. ${ }^{34}$ Dalam hal ini, kitab keagamaan baik Al-Qur'an maupun Alkitab melegitimasi dialog yang terjadi dalam SR berdasarkan pada etika maupun moral yang terkandung dalam masing-masing kitab keagamaan dalam hal mencapai suatu pengenalan dan kerjasama di tengah perbedaan yang diyakini sebagai bagian dari ciptaan Yang Ilahi. Dengan kata lain kitab keagamaan menyediakan suatu modal (tertuang dalam Nilai dasar YIPC, 12 Nilai Perdamaian dan ACW) bagi upaya membangun perdamaian bersama yang dalam SR dilakukan melalui dialog sebagai tujuan kehadiran agama yakni menjadi rahmat bagi seluruh ciptaan.

Sejak semula kegiatan SIPC telah menanamkan nilai-nilai yang membantu setiap peserta dengan latar belakang keyakinan yang berbeda untuk memiliki sikap terbuka dengan tradisi komunitas iman lainnya dengan nilai-nilai perdamaian yang tidak terlepas dari kitab keagamaan dimana imannya dibentuk. ${ }^{35}$ Mulai dari menanamkan nilai dasar YIPC yang sangat erat dengan nilai-nilai yang dikandung dalam komunitas iman Kritsten dan Islam dengan pertama-tama mengakui Keesaan Tuhan serta melandasainya dengan nilai kasih terhadap sesama 2004), 99.

${ }^{32}$ William Deal dan Timothy Beal. Theory For Religious Studies (New York: Routledge,

33 Andrew Rippin, Muslims: Their Religious Beliefs and Practices (New York: Routledge, 2005), 25.

${ }^{34}$ Yusak B. Setyawan, "Konflik dan Kekerasan Bernuansa Keagamaan di Indonesia dalam Perspektif Pandangan Yesus, dalam Injil-injil Kanonis Perjanjian Baru” dalam Perdamaian dan Keadilan (Jakarta: BPK Gunung Mulia, 2017), 18.

${ }^{35}$ Cherian George, Pelintiran Kebencian: Rekayasa Ketersinggungan Agama dan Ancamannya bagi Demokrasi (Jakarta: PUSAD Paramadina, 2017), 272. 
dan lingkungan. Hal ini menjadi suatu dasar bersama di antara kedua komunitas iman yang berbeda namun memiliki nilai yang sama. Tentu hal ini tidak mengherankan mengingat baik agama Kristen maupun Islam menjadi bagian dalam agama Abrahamik yang memegang keyakinan monoteisme dalam memandang realitas Keilahian.

Dengan mendasari dialog antar kedua komunitas iman ini dengan 12 nilai perdamaian yang ditawarkan oleh Lincoln dan Amalee dapat terlihat juga nilainilai dalam kitab keagamaan yang diangkat untuk menumbuhkan pemahaman baik dalam memahami diri sendiri, memahami iman, maupun memahami sesama serta lingkungan. 12 nilai perdamaian menawarkan juga isu-isu bersama yang turut menjadi fokus setiap komunitas iman dalam membangun kehidupan bersama serta bersesama di tengah perbedaan yang ada di dunia. Begitu pun dengan dokumen ACW yang menujukkan bahwa dengan landasan kitab keagamaan masing-masing, baik komunitas iman Kristen maupun Islam justru didorong untuk menciptakan kehidupan yang saling menerima satu dengan yang lain. Dengan nilai-nilai dasar yang sama serta dengan pemahaman akan tugas bersama sebagai umat manusia untuk memelihara keutuhan ciptaan maka SR hadir dalam upaya semakin memperdalam dialog bahkan melampaui dialog karena justru dalam SR proses penerimana itu akan semakin mendalam.

SR tidak menghendaki adanya suatu kesepakatan melainkan sebaliknya justru menampilkan ketidaksepakatan melalui beragam pertanyaan yang diklarifikasi, menonjolkan perbedaan lewat masing-masing teks keagamaan, serta perbedaan keyakinan terhadap sesuatu sebagai hal yang dapat diterima. Setiap individu yang menjadi bagian dalam proses SR dipandang sebagai individu yang berhak menyampaikan pandangan yang berbeda baik berlandaskan refleksi terhadap bagian teks kitab keagamaannya maupun terhadap teks kitab kegamaan lain. Rasa penasaran serta keterbukaan menjadi hal penting yang turut dibangun dalam diskusi yang terjalin untuk lebih merekatkan hubungan antar peserta 
meskipun dalam perbedaan pandangan yang ada. ${ }^{36}$ Dalam SR tentu akan ditemui berbagai perbedaan karena kitab keagamaan yang dibaca pun memiliki konteks serta kebudayaan yang berbeda dengan komunitas iman lainnya.

Dalam komunitas iman Kristen dan Yahudi, Abaraham hendak mengorbankan anaknya Ishak, namun dalam komunitas iman Islam meyakini bahwa Ismael yang hendak dikorbankan, hal ini menjadi salah satu contoh bagaimana dalam SR perbedaan pandangan, perbedaan keyakinan, perbedaan pendapat sangat diterima dan justru akan semakin memperkaya iman dari komunitas masing-masing. Hal ini perlu untuk ditegaskan mengingat begitu banyak pihak yang enggan untuk berdialog, bertemu bahkan bertanya dengan komunitas iman lainnya dengan alasan ketakutan jika imannya akan tergoncang, keyakinannya akan berubah. Justru dalam setiap dialog yang terjadi khususnya dalam SR, keyakinan bukan hanya semakin diperteguh melainkan juga diperkaya dengan niali-nilai yang diterima dari pandangan, interpretasi, serta pendapat komunitas iman lain terhadap komunitas iman diri sendiri.

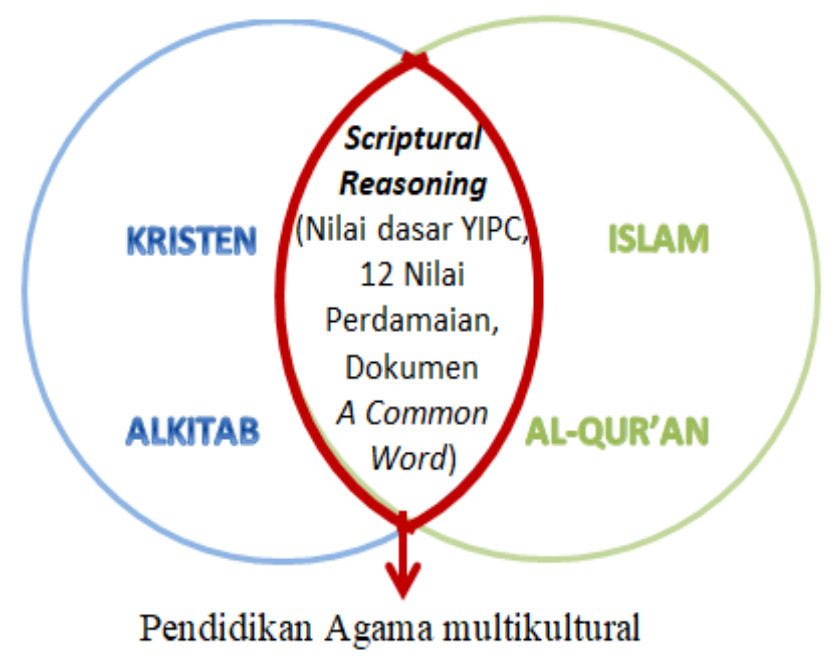

Gambar 1.

36 Bob Ekbald, "Reading Scripture for Good News that Crosses Barriers of Race/Ethnicity, Class, and Culture", Interpretation: Journal of Bible and Theology 65 (Juli, 2011), 231. 
Identitas bersama yang terbentuk atas dasar kitab keagamaan masing-masing komunitas iman sebagai dasar pendidikan agama multikultural Kristen-Islam melalui Scriptural Reasoning.

\section{Scriptural Reasoning sebagai Media Pendidikan Agama Multikultural Kristen-Islam Berbasis Kitab Keagamaan}

SR sebagai suatu model dialog yang mengedepankan peran kitab keagamaan didalamnya menjadi sesuatu yang mampu mentransformasi dialog-dialog yang sebelumnya terjalin antar komunitas iman Kristen dan Islam di Indonesia. Hasil survei yang dilakukan oleh YIPC Indonesia dengan melibatkan fasilitator serta anggota, sebagian besar menunjukkan bahwa SR mampu membantu generasi muda Kristen-Islam untuk memahami ajaran agama satu dengan yang lain serta membentuk individu yang bisa menerima perbedaan agama dan juga menjalin persahabatan lintas agama. ${ }^{37}$ Pada bagian ini SR hendak dilihat sebagai tawaran bagi pelakasanaan pendidikan di lembaga pendidikan formal namun juga mengkaji SR sebagai media dialog yang terbuka dalam menghadirkan ruang pertemuan bagi masyarakat khsusunya generasi muda untuk mengalami dan berjumpa dengan perbedaan.

Indonesia pada khususnya, dan Asia pada umumnya, sangat kental dengan keberagaman. Realitas plural tidak dapat dilepaskan dari negara-negara di Asia dan telah menjadi identitas Asia. ${ }^{38}$ Begitu pun dengan Indonesia yang memiliki realitas keberagaman baik dari segi suku, ras, etnis terlebih agama. Keberagaman tersebut tak jarang menghasilkan permasalahan akibat gesekan antar kelompok, ras, etnis, bahkan agama. Di samping harus menghadapi permasalahan kemiskinan, perjuangan serta penderitaan, masyarakat Asia juga dihadapkan dengan permasalahan konflik agama yang lebih banyak memakan korban dibanding permasalahan kelaparan maupun penyakit. ${ }^{39}$ Hal iniah yang menjadi konteks Asia. Dalam sejarah Indonesia sendiri, konflik antar agama menjadi

37 YIPC Indonesia. Laporan Tahunan YIPC Indonesia 2018. http://yipci.org/laporantahunan-yipc-indonesia-2018 (diakses 22 Januari 2020).

38 Hope S. Antone, endidikan Kristiani Kontekstual: Mempertimbangkan Relaitas Kemajemukan dalam Pendidikan Agama (Jakarta: BPK Gunung Mulia, 2015), 2.

${ }^{39}$ Antone, Pendidikan Kristiani Kontekstual, 4. 
bagian kelam kehidupan berbangsa dan bernegara, sebagai contoh adalah konflik Ambon dan Poso. Tidak hanya itu, konflik-konflik yang mengancam kehidupan bersama juga masih terus terjadi dengan berbagai larangan untuk melakukan kegiatan keagamaan terhadap kelompok-kelompok yang secarah jumlah lebih sedikit. Regulasi yang dihasilkan oleh pemerintah pun masih meguntungkan kelompok mayoritas dan menekan kelompok minoritas. ${ }^{40}$ Permasalahan ini menurut Hope S. Antone semakin diperparah oleh ketidaktahuan akan agamaagama lain, sikap intoleran dan kecurigaan terhadap agama-agama lain serta berkembangnya sikap fanatisme dan fundamentalisme agama. ${ }^{41}$

Menghadapi realitas yang seperti ini, pendidikan memiliki peran besar untuk menjadi jawaban atas konflik yang sering terjadi di antara komunitaskomunitas iman yang berbeda. Dalam membangun solidaritas di tengah konteks keberagaman, perlu diawali dengan sikap penghargaan serta penerimaan terhadap perbedaan. Pemahaman seperti ini dapat ditanamkan dalam proses belajar dari orang lain yang terwujud dalam dialog dimana proses saling belajar dan mengajar dapat terjadi. ${ }^{42}$ Maka dari itu pendidikan yang dilaksanakan pun diupayakan untuk mampu sejalan dengan konteks serta permasalahan yang dihadapi dalam konteksnya. Dalam hal ini peran guru pun sangat diperlukan dalam membuka wawasan naradidik terhadap perbedaan. ${ }^{43}$ Maka dari itu, menjadi perlu bagi pihak-pihak terkait dalam hal ini pendidik, penyelenggara pendidikan, hingga pemangku kepentingan untuk menghadirkan cara atau metode mendidik yang mengedepankan penerimaan terhadap perbedaan. Metode yang digunakan dalam pendidikan khsusunya pendidikan agama perlu untuk dikembangkan sehingga dapat mencegah naradidik dari sifat eksklusif dan fanatis. Harus diakui bahwa hal in menjadi tugas bersama karena berbicara soal pendidikan selalu memiliki keterkaitan dengan berbagai pihak. Maka dari itu, transformasi pendidikan agama

\footnotetext{
${ }^{40}$ Halili, Supremasi Intoleransi (Jakarta: Pustaka Masyarakat Setara, 2016), 95.

${ }^{41}$ Antone, Pendidikan Kristiani Kontekstual, 6.

${ }^{42}$ Izak Y.M. Lattu, Menolak Narasi Tunggal: Diskursus Agama, Pluralisme, dan Demokras (Salatiga: Satya Wacana University Press, 2018), 155.

${ }^{43}$ Ida Retnawati, "Peran Guru dalam Pendidikan Multikulturalisme", dalam Mengelola Keragaman di Sekola: Gagasan dan Pengalaman Guru, ed. Suhadi, Linah Pary, Fardan Imamah, Marthen Tahun, (Yogyakarta: CRCS UGM, 2016), 92.
} 
menjadi pendidikan yang berbasis pendidikan multikultural harus dijalankan secara simultan. Pendidikan agama berbasis pendidikan multikultural tidak hanya bergantung pada metode saja melainkan juga pada kurikulum yang digunakan, dan dalam hal ini peran pemangku kepentingan sangat dibutuhkan. ${ }^{44}$

Pendidikan agama perlu untuk mengembangkan pendidikan perdamaian yang berbasis pada pengalaman. Pengalaman bertemu dengan komunitas iman yang berbeda memiliki peran yang sangat besar dalam menumbuhkan rasa penerimaan serta rasa toleransi. Dalam hal ini keberagaman dilihat sebagai hal yang wajar untuk diterima. Hal seperti ini dikenal juga dengan pendidikan religiusitas dimana konsep pendidikan agama yang dikelompok-kelompokan sesuai dengan agama masing-masing perlu untuk dikaji kembali. Pengelompokan dalam pendidikan agama justru membatasi bahkan menghilangkan ruang interaksi antar naradidik dalam perbedaan keyakinan. Pendidikan agama yang terlepas dari pengelompokan agama masing-masing naradidik menjadi hal yang dapat dipertimbangkan untuk dilaksanakan dalam kontek pendidikan perdamaian bagi naradidik. $^{45}$

Selain mempertimbangkan kembali model pendidikan agama yang mengelompokkan naradidik sesuai agamanya masing-masing, model pendidikan berbasis pendidikan agama multikultural juga dapat dilaksanakan dengan mengacu pada konteks kebudayaan masyarakat setempat. Hope S. Antone menawarkan suatu model pendidikan yang mengadopsi kebudayaan masyarakat Asia pada umumnya yakni model Mealtable Sharing atau percakapan di meja makan yang telah lumrah ditengah kehidupan masyarakat Asia dimana berkumpul dan berbincang-bincang saat menikmati makanan mampu menghadrikan dialog bahkan multilog yang mempersatukan perbedaan. ${ }^{46}$ Model yang ditawarkan oleh Antone memang lebih dekat dengan kehidupan dan kebudayaan masyarakat Asia terlebih dalam berbagai perayaan-perayaan khusus seperti hari raya keagamaan,

\footnotetext{
${ }^{44}$ Lattu, Menolak Narasi Tunggal, 157.

${ }^{45}$ Daniel Nuhamara, Pembimbing Pendidikan Agama Kristen (Bandung: Jurnal Info Media, 2009), 102-104.

${ }^{46}$ Hope S. Antone, Pendidikan Kristiani Kontekstual: Mempertimbangkan Relaitas Kemajemukan dalam Pendidikan Agama (Jakarta: BPK Gunung Mulia, 2015), 95.
} 
hari-hari khsusus pengucapan syukur dan sebagainya. Model berbasis budaya seperti ini dapat diterapkan pula dalam dialog lintas iman Kriten-Islam dengan memanfaatkan momen-momen khusus hari raya keagamaan masing-masing. Seperti halnya saat bulan puasa banyak dilaksanakan buka puasa bersama yang tidak jarang meilibatkan komunitas iman lain. Namun dalam hal menghadirkan dialog berbasis kitab keagamaan, SR dapat menjadi metode dalam pendidikan agama multikultural yang juga dapat diterapkan pada lembaga pendidikan.

SR hadir dengan landasan identitas agama masing-masing dalam hal ini kitab keagamaan. Mendiskusikan refleski terhadap bagian dari kitab keagamaan yang diyakini maupun kitab keagamaan keyakinan lain menjadi suatu model pendidikan yang juga menyangkut empat pilar pendidikan dimana peserta SR tidak hanya didorong untuk mengalami pengetahuan (aspek kognitif) terhadap keyakinan yang berbeda dengan kitab keagamaannya (learning to know), juga tidak hanya didorong untuk secara langsung melakukan dialog dengan yang berbeda dari dirinya (aspek motorik) untuk menerima perbedaan tersebut (learning to do), serta tidak hanya didorong untuk menghidupi nilai-nilai kesadaran dan penerimaan akan keberagaman dalam kehidupan sehari-hari (learning to be), namun juga didorong untuk mau hidup bersama dan bersesama dengan orang yang berbeda keyakinan untuk membangun solidaritas bersama (learning to live together) atas dasar nilai-nilai keagamaan yang bersumber dari refleksi kitab keagamaan dalam $\mathrm{SR}^{47}$

Pada dasarnya komunikasi yang terjadi dalam dialog yang tercipta di SR, menjadikan nilai-nilai keagamaan yang terkandung dalam kitab keagamaan sebagai bekal bagi keimanan diri sendiri namun disisi lain juga sebagai landasan untuk berelasi terlebih mengalami yang lain dalam kehidupan bersama. Menjadi sangat perlu untuk menghadirkan ruang-ruang interaksi lintas iman. SR mampu menjadi sarana bagi interaksi komunitas iman Kristen dan Islam yang mampu

\footnotetext{
${ }^{47}$ Mohamad Yusuf et al., Politik Pendidikan Agama Kurikulum 2013 dan Ruang Publik Sekolah (Yogyakarta: CRCS UGM, 2014), 7-8.
} 
menghasilkan perubahan pemahaman terhadap yang lain. ${ }^{48}$ Mengimplementasikan SR dalam proses pendidikan agama pada tingkat dasar hingga perguruan tinggi tentu harus dipikirkan, dan dipertimbangkan serta dipersiapkan dengan matang. Hal ini memerlukan kerja keras yang membutuhkan peran banyak pihak baik dari pendidik, penyelenggara pendidikan, hingga pemangku kepentingan dalam bidang pendidikan.

SR sebagai suatu ruang pertemuan kedua identitas keagamaan dengan melandasakan dialog pada kitab keagamaan masing-masing komunintas menjadi suatu media belajar bagi masyarakat khususnya bagi generasi muda. Dalam hal ini terdapat beberapa hal yang perlu untuk dilihat berkaitan dengan keberadaan SR sebagai ruang untuk mengalami perbedaan.

a. Pertama, dialog yang berlangsung dalam SR dibangun atas dasar kitab keagamaan yang menyentuh dasar keyakinan masing-masing komunitas agama. Dalam hal ini kitab keagamaan didalami secara bersama-sama dengan saling menghormati pandangan yang ada.

b. Kedua, dialog yang tercipta lebih bersifat santai dan tidak seformal dialogdialog lintas iman lainnya sehingga mampu menarik minat generasi muda untuk saling bertukar pandangan. Dengan demikian SR menjadi ruang yang menghadirkan pengalaman bagi masing-masing komunitas untuk mengalami perbedaan diatas tujuan yang sama yakni untuk dapat saling memahami dan menerima serta memperkaya pengetahuan terhadap tradisi iman yang berbeda.

c. Ketiga, SR dilaksanakan secara berkala sehingga mampu membangun suatu komunitas bagi generasi muda yang kreatif dalam pergerakan narasi perdamaian maupun keadilan ditengah tantangan kemajemukan yang menjadi realitas bangsa. Melalui SR generasi muda yang melek perbedaan mampu tercipta serta mampu menjadi agen-agen perubahan pola pikir terhadap keyakinan yang lain atas dasar pengalaman bersama. SR menjadi salah satu

${ }^{48}$ Robert Schreiter, "Just What Do We Want? Ministry in a Multicultural World", New Theology Review 13 (2000), 5-6. 
cara untuk mencegah terjadinya konflik maupun gesekan antar kelompok atas dasar keyakinan yang berbeda dengan mengharikan dialog-dialog sebagai cara untuk saling memahami dan memiliki pengalaman terhadap perbedaan.

\section{Penutup}

Mempertemukan dua komunitas iman yang berbeda menjadi tugas besar dan juga tugas bersama. Ruang interaksi terhadap perbedaan perlu untuk dihadirkan kembali, dan SR menjadi salah satu ruang interaksi komunitas iman Kristen-Islam sebagai wadah untuk saling belajar memahami dan menerima. SR yang menyasar kalangan muda menjadi bagian dari langkah mentransformasi masyarakat dalam mewujudkan masyarakat yang terbuka serta menerima perbedaan. SR mampu menghadrikan gambaran baru dalam memandang serta memahami kitab keagamaan dimana kitab keagamaan yang memuat ideologi, keyakinan dan yang mengatur kehidupan keagamaan seseorang justru mampu menjadi landasan untuk saling berinteraksi dan menciptakan solidaritas ditengah perbedaan. Pada akhirnya mengembangkan berbagai model pendidikan yang berlandaskan pada prinsip pendidikan perdamaian serta menghadrikan ruang pertemuan dimana masyarakat mampu mengalami perbedaan, menjadi tugas bersama, dan menjadi tugas yang panjang dalam menghadirkan masyarakat multikultural Indonesia yang mampu menerima serta menghargai perbedaan yang ada.

\section{Daftar Referensi}

Antone, Hope S., Pendidikan Kristiani Kontekstual: Mempertimbangkan Relaitas Kemajemukan dalam Pendidikan Agama. Jakarta: BPK Gunung Mulia, 2015.

BBC Indonesia. Pelajar SMA di Padang, Sukabumi, dan Solo dianggap Paling Rentan https://www.bbc.com/indonesia/amp/indonesia-42832938 (diakses $17 \mathrm{Mei}$ 2020).

Baidhawy, Zakiyuddin., Pendidikan Agama Berwawasan Multikultural. Jakarta: Erlangga, 2005

Bellah, Robert N., Beyond Belief: Essays on Religion in a Post-Traditional World. Berkley: University of California Press, 1970.

Deal, William, dan Timthy Beal. Theory For Religious Studies. New York: Routledge, 2004. 
Ekbald, Bob. "Reading Scripture for Good News that Crosses Barriers Of Race/Ethnicity, Class, and Culture", Interpretation: Journal of Bible and Theology 65. Juli, 2011.

Ford, David, E. Jews, Christians, and Muslims Meet around their Scriptures: An Interfaith Practice for the $21^{\text {st }}$ Century. Rome: The Russell Berrie Foundation, 2011.

.Fields of Faith: Theology and Religious Studies for the Twenty-First Century. New York: Cambridge University Press, 2005.

"An Interfaith Wisdom: Scriptural Reasoning Between Jews, Christians, and Muslims", Modern Theology 22. Juni, 2006.

Geroge, Cherian. Pelintiran Kebencian: Rekayasa Ketersinggungan Agama dan Ancamannya bagi Demokrasi. Jakarta: PUSAD Paramadina, 2017.

Halili, Supremasi Intoleransi. Jakarta: Pustaka Masyarakat Setara, 2016.

Ibrahim, Ruslan. "Pendidikan Multikultural: Upaya Meminimalisisr Konflik di Era Pluralitas Agama”, el-Tarbawi: Jurnal Pendidikan Islam. 2008.

Lattu, Izak Y.M., Menolak Narasi Tunggal: Diskursus Agama, Pluralisme, dan Demokrasi. Salatiga: Satya Wacana University Press, 2018.

"Beyond Interreligious Dialogue: Oral-Based Interreligious Engagements in Indonesia", dalam Interreligious Dialogue: From Religion to Geopolitics, ed. Giuseppe Giordan dan Andrew P. Lynch, Boston: Brill, 2019.

Lincoln, Erick, dan Irfan Amalee. Peace Generation: 12 Nilai Dasar Perdamaian. Bandung: Pelangi Mizan, 2007.

Murdianto. "Stereotipe, Prasangka dan Resistensinya: Studi Kasus pada Etnis Madura dan Tionghoa di Indonesia". Qalamuna: Jurnal Pendidikan, Sosial, dan Agama 2(10) 2018, 137-160. https://doi.org/10.5281/zenodo.3559267

Nuhamara, Daniel. Pembimbing Pendidikan Agama Kristen. Bandung: Jurnal Info Media, 2009.

Ochs, Peter. "Scripture", dalam Fields of Faith: Theology and Religious Studies for the Twenty-First Century. New York: Cambridge University Press, 2005.

Ooi, Giok Ling dan Chee Min Fui, “They Play Soccer too!-Madrasah Education in Multicultural Singapore", Asia Pasific Journal of Education 27, Maret, 2007.

Race, Richard, Multiculturalism and Education. London: Continuum, 2011.

Retnawati, Ida., "Peran Guru dalam Pendidikan Multikulturalisme", dalam Mengelola Keragaman di Sekolah: Gagasan dan Pengalaman Guru, ed. Suhadi, Linah Pary, Fardan Imamah, Marthen Tahun. Yogyakarta: CRCS UGM, 2016.

Rippin, Andrew, Muslims: Their Religious Beliefs and Practices. New York: Routledge, 2005.

Robert, Jackson, Rethinking Religious Education and Plurality. New York: Routledge Falmer, 2004.

Saliba, John A., Understanding New Religious Movements. Oxford: AltaMira, 2003. 
Schreiter, Robert . "Just What Do We Want? Ministry in a Multicultural World", New Theology Review 13. 2000.

SETARA Institute. Tipologi Keragaman Mahasiswa: Survei di 10 Perguruan Tinggi Negeri.Jakarta: SETARA Institute, 2019.

Setyawan, Yusak, B. "Encountering State Ideology: Reading the Bible from an Indonesian Postcolonial Perspective" dalam Colonial Contexts and Postcolonial Theologies: Storyweaving in The Asia-Pasific, ed. Mark G. Brett dan Jione Havea. New York: Palgrave Macmillan, 2014.

"Kitab Keagamaan, Ideologi, Budaya dan Komunitas" dipresentasikan dalam kelas Mata Kuliah Kitab-Kitab Keagamaan dan Masyarakat untuk Magister Sosiologi Agama Fakultas Teologi UKSW, Salatiga, 2019.

"Konflik dan Kekerasan Bernuansa Keagamaan di Indonesia dalam Perspektif Pandangan Yesus dalam Injil-injil Kanonis Perjanjian Baru. Dalam Perdamaian dan Keadilan Dalam Konteks Indonesia yang Multikultural dan Beragam Tradisi Iman. Jakarta: BPK Gunung Mulia, 2017.

Susanto, Edi., "Pendidikan Agama Berbasis Multikultural: Upaya Strategis Menghindari Radikalisme", KARSA, April, 2006.

Yusuf, Muhammad,. Marthen Tahun, Budi Asyari, Sudarto, Politik Pendidikan Agama Kurikulum 2013 dan Ruang Publik Sekolah. Yogyakarta: CRCS UGM, 2014.

YIPC Indonesia, Laporam Tahunan YIPC Indonesia 2018. Yogyakarta:YIPC. http://yipci.org/laporan-tahunan-yipc-indonesia-2018 (diakses 22 Januari 2020)

(c) 2020 pada penulis. Diterbitkan oleh LP2M INSURI Ponorogo, artikel jurnal ini dapat diakses secara terbuka dan memiliki lisensi CC-BY-SA (https://creativecommons.org/licenses/by-sa/4.0/). 